\title{
LEVELS OF LEAF HERBIVORY IN AMAZONIAN TREES FROM DIFFERENT STAGES IN FOREST REGENERATION
}

\author{
Heraldo L. VASCONCELOS'
}

\begin{abstract}
Leaves from 120 canopy trees and 60 understory tree saplings growing in primary and secondary forests near Manaus, Brazil, were collected for determination of standing levels of herbivory (percent leaf area lost). Overall, levels of herbivory on leaves of central Amazonian trees were low. About one quarter of the leaves examined $(n=855)$ had no damage at all. In most other Neotropical sites studied the mean percentage of herbivory was found to vary between 5.7 and $13.1 \%$, whereas in Manaus it was only $3.1 \%$. The data presented here support the contention that levels of herbivore damage are positively related to soil fertility. No significant difference was found in herbivory levels between canopy trees and understory saplings. Also, there was no difference in damage between leaves from pioneer and late successional trees. Field assays of preference, however, revealed that leaves from pioneer trees are more palatable to leaf-cutting ants (Atta laevigata). This effect was dependent upon leaf age, being observed in mature leaves, but not in young leaves. The greater rate of leaf production in secondary forests may be a factor accounting for the greater abundance of leaf-cutting ants in secondary compared to primary forests.
\end{abstract}

Key-words: ants, Atta laevigata, herbivory, insect-plant interactions, Amazon forest

\section{Niveis de Dano Foliar por Herbívoros em Árvores Amazônicas de Diferentes Estágios na Regeneração Florestal.}

RESUMO - Folhas de 120 árvores do dossel e de 60 arvoretas do sub-bosque foram coletadas em florestas primárias e secundárias de terra-firme próximas a Manaus, para medição dos niveis de herbivoria (porcentagem da área foliar danificada por herbivoros). Os niveis de herbivoria foram baixos. Cerca de $25 \%$ das folhas examindas $(n=855)$ não tinham dano algum. Na maioria das outras florestas Neotropicais estudadas a porcentagem media de herbivoria ficou entre $5,7 \mathrm{e}$ $13,1 \%$, enquanto em Manaus este valor foi de apenas 3,1\%. Os dados apresentados aqui dão apoio a hipótese de que os niveis de herbivoria são positivamente relacionados a fertilidade do solo. Não houve diferença no nivel de herbivoria entre árvores do dossel e arvoretas do subbosque. Também, não encontrou-se diferença entre folhas de plantas pioneiras da mata secundária e aquelas de final de sucessão encontradas na mata primária. Testes de preferência, entretanto, mostraram que folhas das plantas pioneiras são mais palatáveis as saúvas (Atta laevigata). Este efeito foi dependente da idade foliar, tendo sido observado $\mathrm{em}$ folhas maduras mas não $\mathrm{em}$ folhas jovens. A maior taxa de produção de folhas na floresta secundária pode ser um dos fatores responsáveis pela maior abundância de saúvas na mata secundária do que na mata primária.

Palavras-chave: formigas, Alta laevigata, herbivoria, floresta Amazônica, interações inseto-planta

\section{INTRODUCTION}

The relative contribution of herbivores to nutrient cycling and energy flow in the ecosystem depends primarily on the amount of plant production consumed by these animals. Many studies on forest ecosystems have used standing levels of herbivory (percent leaf area lost at a given point in time) as an estimate of plant consumption (e.g., Jordan \& Uhl, 1978; Adis et al.,

'Coordenação de Pesquisas em Ecologia, Instituto Nacional de Pesquisas da Amazônia (INPA), Cx. Postal 478, 69011-970 Manaus, AM, Brazil 
1979). This measure tends to underestimate actual herbivory rates (Lowman, 1984; Filip et al. 1995), but in many cases it is the only measure possible, given the logistic limitations of continued access to the forest canopy. Regardless of methodological problems, herbivory levels in terrafirme (upland) forests of central Amazonia appear lower than in other tropical forests (Fittkau \& Klinge, 1973), but comparative data is lacking. In a study on biomass and trophic structure of a terra-firme forest near Manaus, Fittkau \& Klinge (1973) noticed that leaves do not show any signs of heavy attack by animals, and argued that this might be correlated with the low nutrient content of leaves from the forest of that region. Leaf nutrient content is usually low in tropical trees growing in nutrient-poor soils (Vitousek \& Sanford, 1986), such as near Manaus. Furthermore, when nutrients are limiting, plants tend to allocate more resources to the production of secondary compounds (Coley et al., 1985). Thus, the combination of a low leaf nutritional value and high content of secondary chemicals may keep herbivore populations at low levels in forests growing on poor soils.

Leaf-cutting ants (Atta spp.) are perhaps the most conspicuous and important herbivores in many tropical forest sites. Wint (1983), for instance, reported that Atta was responsible for as much as $80 \%$ of the leaf damage in the canopy of the Panamanian forest he studied. In contrast, leaf-cutting ants are extremely rare in some parts of Amazonia and Venezuela, particularly in the primary forest (Vasconcelos, 1988; Jaffe \& Villela, 1989), although when forest is cleared and the area left to regrowth, ant nest densities increase substantially (Vasconcelos \& Cherrett, 1995). Such an increase may result from changes in abiotic conditions, particularly increased light, since Atta nests appear to develop poorly in shady conditions (Jaffe \& Vilella, 1989; pers. obs.). Alternatively, leaf-cutting ant populations may increase after primary forest is cleared because of changes in plant resources. Leaves from pioneer tree species which colonize cleared areas, may be more palatable to leafcutting ants because of lower investment in the production of certain defensive compounds than late successional species from mature forest (Coley, 1983; Coley et al., 1985). In this paper, I test the hypothesis that trees from different stages in forest regeneration differ in their palatability to leaf-cutting ants, by conducting assays of leaf preference with field colonies of Atta laevigata (Fr. Smith). Standing levels of herbivory were also measured on leaves of trees from different stages in forest regeneration, as a way of comparing overall levels of herbivory among different forest types. Finally, standing levels of herbivory were used to obtain a preliminary comparison of herbivory levels in forests near Manaus versus those in other Neotropical sites. 


\section{METHODS}

\section{Study sites}

The study was conducted in, or in areas immediately adjacent to, the Reserva Florestal Adolfo Ducke and the Estação Experimental de Silvicultura Tropical of INPA, located respectively, 28 and $45 \mathrm{~km}$ north of Manaus ( $3^{\circ} 05^{\prime} \mathrm{S}$, $\left.60^{\circ} 00^{\prime} \mathrm{W}\right)$, Brazil. Precipitation in Manaus averages $2100 \mathrm{~mm}$ annually and varies seasonally, with a rainy period between November and May and a dry period between June and October (Ribeiro, 1976). Most of the vegetation in the study areas consists of undisturbed, primary forest, characterized by a high diversity of tree species (most of which represented by less than one adult individual per ha), a canopy height of about $35 \mathrm{~m}$, with some emergent trees reaching up to $50 \mathrm{~m}$, and a relatively open understory with many stemless palms (Guillaumet, 1987). In a few areas, however, secondary forests were present due to primary forest clearing and burning 7-10 years ago. The secondary forests studied were dominated by trees, $6-10 \mathrm{~m}$ in height, of the genus Vismia (Guttiferae). Forests dominated by Vismia are common in areas of central Amazonia that have been subjected to moderate use as pasture or agriculture (Lucas et al., 1998).

\section{Measurements of foliar herbivory}

Leaves from 60 primary-forest understory-saplings, from 60 primaryforest canopy-trees, and from $60 \mathrm{sec}$ ondary-forest canopy-trees were collected. For this, I established six line transects in primary forest and six in secondary forest. The transects were 45 $\mathrm{m}$ long and at least $200 \mathrm{~m}$ apart. Ten trees and 10 saplings (primary forest only) were then chosen at random, maintaing a minimum distance of $5 \mathrm{~m}$ between trees. Climbing and the use of a pruner was necessary to collect leaves from canopy trees in primary forest.

The number of species sampled in each forest habitat or forest strata was variable. Fifty-two species of canopy trees and 49 species of saplings were found in primary forest. The secondary forest was less diverse and, among the 60 selected trees, 31 species were found, of which three species of Vismia, together, comprised $38 \%$ of the sampled trees. Other common species in secondary forest were Goupia glabra (Celastraceae) and Bellucia sp. (Melastomataceae). All of these are typically pioneer species, none of which were found in the transects established in primary forest, where only late successional species were recorded.

To minimize variation in leaf age, only mature, fully expanded leaves were collected for determination of the amount of herbivory. Herbivory (percent total leaf area lost to herbivores) was determined using a transparent plastic grid with precision of $0.25 \mathrm{~cm}^{2}$. From each selected plant, 3 to 6 leaves were measured.

\section{Assays of preference with leaf- cutting ants}

In this experiment leaves from the same canopy trees described above 
were used. I used leaves from canopy trees only because leaves growing in shady conditions, such as those in the forest understory, differ from those in the canopy in terms of their nutritional and defensive characteristics against leaf-cutting ants (Hubbell \& Wiemer, 1983; Nichols-Orians, 1991). I determined plant palatability to leaf-cutting ants (or their fungus) by placing leaves alongside an active foraging trail. Comparisons were made between leaves from trees in primary forest versus those in secondary forest (i.e., between late successional versus pioneer trees).

Six tests (assays) with two $A$. laevigata colonies were done. In each assay, leaves from 10 pioneer and 10 late successional trees were presented simultaneously. When young and mature leaves from a given tree were available, both were presented (one of each type), otherwise only the mature leaf was given. The position of the leaves from different trees along the trail was determined at random. The contour of each test leaf was drawn on a piece of paper before and 1 hour after the assays, and the area removed by the ants measured using a transparent plastic grid. Leaves used in the assays were collected a few hours prior to their use, and were kept fresh in sealed polythene bags on crushed ice.

\section{RESULTS}

\section{Levels of leaf herbivory}

Overall levels of leaf herbivory were low. About one quarter of the leaves examined had no damage at all, and more than two-thirds of the leaves had less than 3\% damage (Fig. 1). No significant difference in leaf herbivory was found between pioneer and late successional trees (Mann-Whitney Utest, $n_{1}=285, n_{2}=296, p=0.41$ ) nor between understory saplings and canopy trees (Mann-Whitney U-test, $\mathrm{n}_{1}=285, \mathrm{n}_{2}=274, \mathrm{p}=0.72$; Fig. 1). The mean ( \pm 1 S.E.) percent of damage in leaves of pioneer trees from the secondary forest canopy was $2.6 \pm 0.3$ $\%(n=296)$, whereas in late successional trees from the primary forest canopy it was $2.9 \pm 0.3 \%(n=285)$. The percent of leaf damage in saplings of late successional trees growing in the primary forest understory was $3.8 \pm 0.5 \%(n=274)$.

Damage by leaf miners and by galling insects was rare. Less than $4 \%$ of the leaves presented damage by these types of herbivores (Tab. 1). The incidence of necrosis or of skelotinized leaves was greater; these types of damage were recorded in 10 to $15 \%$ of the leaves. The most common type of damage, observed in over $60 \%$ of leaves, was caused by chewing insects (Tab. 1).

\section{Assays of preference}

Although there was no difference in standing levels of leaf herbivory between pioneer and late successional trees, field assays of preference with the leaf-cutting ant $A$. laevigata revealed that the former tend to be more palatable. The mean area cut by ants from mature leaves of pioneer trees was 2.7 times greater than that removed from late successional trees 


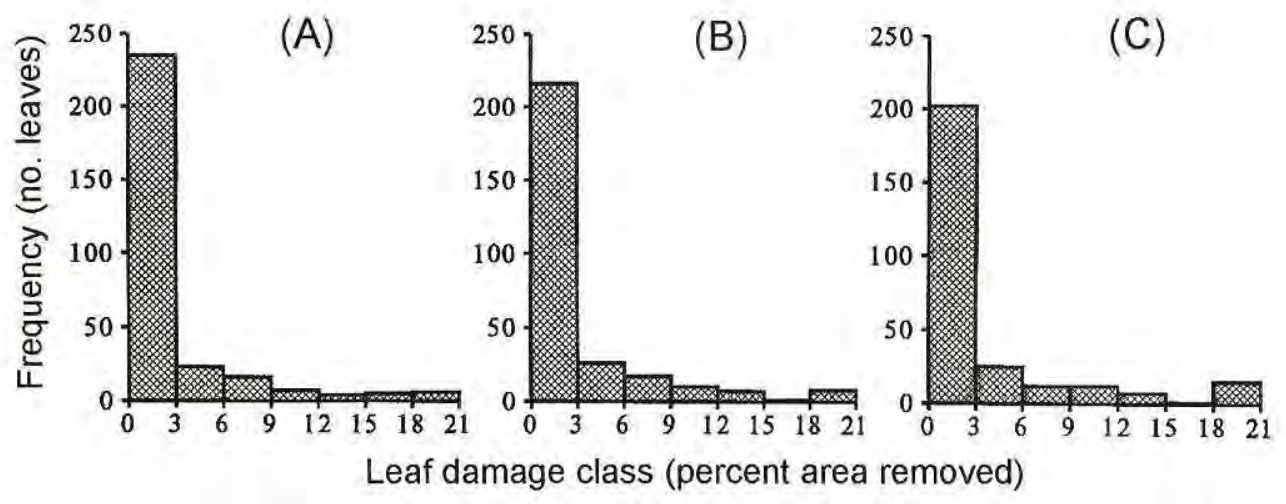

Figure 1. Frequency distribution of leaf herbivore damage in (A) pioneer trees from secondary forest canopy, (B) late successional trees from primary forest canopy, and (C) saplings of late successional trees growing in primary forest understory.

Table 1. Types of leaf damage in canopy trees and understory tree saplings from forests near Manaus, Brazil. Values represent the percentage of examined leaves showing that type of damage. Note that the same leaf could have been assigned to more than one damage category.

\begin{tabular}{lccccc}
\hline & \multicolumn{5}{c}{ Type of Leaf Damage } \\
\cline { 2 - 6 } HABITAT & $\begin{array}{c}\text { Caused } \\
\text { by Miners }\end{array}$ & $\begin{array}{c}\text { Caused } \\
\text { by Galls }\end{array}$ & $\begin{array}{c}\text { Skelotinized } \\
\text { or with } \\
\text { Necrosis }\end{array}$ & $\begin{array}{c}\text { Caused by } \\
\text { Chewing } \\
\text { Insects }\end{array}$ & $\begin{array}{c}\text { Not } \\
\text { Damaged }\end{array}$ \\
\hline Secondary forest canopy & 1.0 & 3.1 & 11.2 & 66.3 & 28.0 \\
Primary forest canopy & 3.3 & 2.4 & 15.3 & 70.3 & 25.9 \\
Primary forest understory & 1.5 & 0.6 & 15.6 & 72.7 & 24.2 \\
\hline
\end{tabular}

* including physical damage which could not be distinguished from damage by chewing insects.

(Tab. 2). However, given the wide variation in area cut from different leaves, the difference was only close to significance (Mann-Whitney U-test, $\left.\mathrm{n}_{1}=56, \mathrm{n}_{2}=58, \mathrm{p}=0.066\right)$. In contrast, the mean area cut from young leaves of pioneer trees did not differ from that of late successional trees (MannWhitney U-test, $\mathrm{n}_{1}=27, \mathrm{n}_{2}=14, \mathrm{p}=$ 0.52 ). Consumption of young leaves by leaf-cutting ants was much greater than of mature leaves (Mann-Whitney U-test, $\mathrm{p}<0.001$; Tab. 2)

\section{DISCUSSION}

Overall, standing levels of leaf herbivory in trees and saplings from forest near Manaus were lower than those found in most other Neotropical forest sites from which data with comparable methodology are available. In these sites, the mean percentage of damage was found to vary between 5.7 and $13.1 \%$, whereas in Manaus it was only $3.1 \%$ (Fig. 2). Only San Carlos de Rio Negro, in Venezuela (Jordan \& Uhl, 1978; Uhl 1987), shows herbivory lev- 
Table 2. Area removed $\left(\mathrm{cm}^{2}\right)$ by leaf cutting ants (Atta leavigata) from leaves of pioneer and late successional trees during leaf preference assays. Values are the mean (S.D.) area removed 1 hour after detached leaves were presented alongside an active ant foraging trail. In each assay $(n=6)$, leaves from 10 pioneer and 10 late successional trees were presented to the ants.

\begin{tabular}{lcccc}
\hline \multirow{2}{*}{ Leaf Age } & \multicolumn{2}{c}{$\begin{array}{c}\text { Pioneer trees from secondary } \\
\text { forest canopy }\end{array}$} & $\begin{array}{l}\text { Late successional trees from } \\
\text { primary forest cannopy }\end{array}$ \\
\cline { 2 - 5 } & Means (SD) & $\begin{array}{c}\text { No. leaves } \\
\text { tested }\end{array}$ & Mean (SD) & $\begin{array}{c}\text { No. leaves } \\
\text { tested }\end{array}$ \\
\hline Young & 1.0 & 3.1 & 11.2 & 66.3 \\
Mature & 3.3 & 2.4 & 15.3 & 70.3 \\
\hline
\end{tabular}

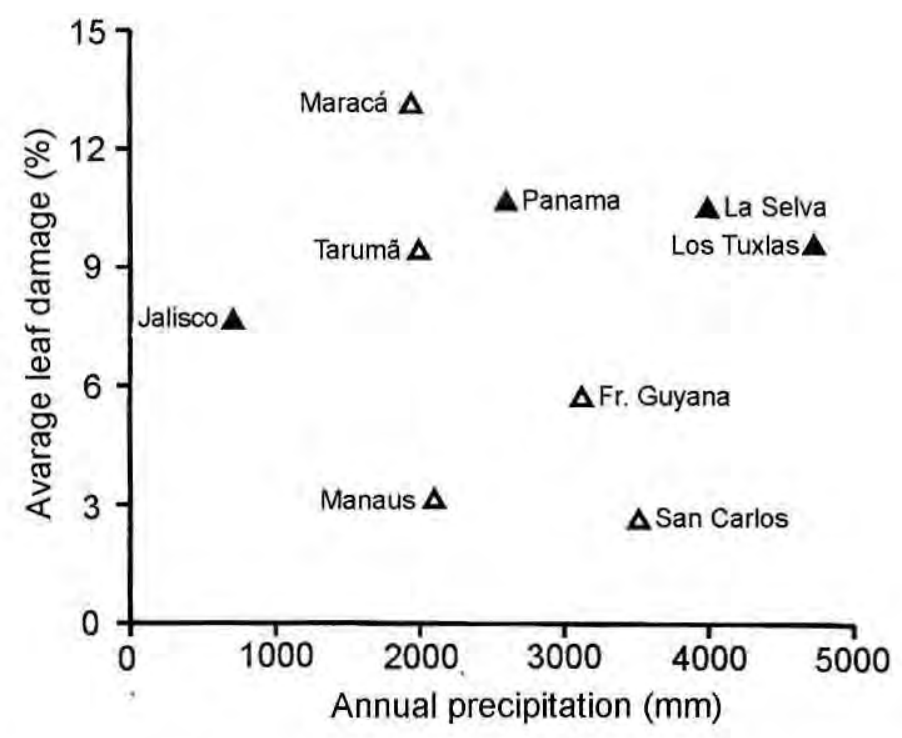

Figure 2. Average levels of herbivore damage (percent leaf area lost) in nine Neotropical forest sites with varying soil conditions and rainfall regimes. Open symbols represent sites with unfertile soils, and filled symbols those with moderately fertile soils. Data from: Manaus (this study), San Carlos (Jordan \& Uhl, 1978; Uhl 1987), French Guyana (Newbery \& de Foresta, 1985; Sterck et al., 1992), Jalisco (Filip et al., 1995), Tarumã (Adis et al., 1979), Los Tuxlas (Dirzo, 1984; de la Cruz \& Dirzo, 1987), La Selva (Marquis \& Braker, 1994), Panama (Wint 1983, Leigh \& Smythe, 1978), Maracá (Nascimento \& Proctor, 1996). 
els as low as those presented here. Variation in standing levels of leaf herbivory across different Neotropical sites was not correlated to annual precipitation $\left(\mathrm{r}_{\mathrm{s}}\right.$ $=-0.08$, n.s.). There were also no clearcut differences in herbivory levels between forests growing on unfertile soils, namely those from the Amazon basin, versus those growing on moderately fertile (volcanic) soils in Central America (Fig. 2). However, with the exception of the studies in Maracá Island (Nascimento \& Proctor, 1994) and in the igapó forest at Tarumã-Mirim River (Adis et al., 1979), levels of herbivory in forests growing on nutrient-poor soils are lower than those reported for sites on more fertile soils. The study by Adis et al. (1979) at the Tarumã-Mirim was in seasonally-flooded forest and, therefore, may not be comparable with the other studies, all conducted in upland forests. On Maracá Island, the concentration of some nutrients ( $\mathrm{P}$ e $\mathrm{K}$ ) are similar to those reported for other forests on moderately fertile soils (Villela, 1998), indicating that soils on that island are not as poor as those in Manaus or San Carlos. Therefore, the possibility that soil fertility may in part explain differences in herbivory levels between different Neotropical sites cannot be ruled out.

Studies with five Australian tree species indicate that herbivory is greater on understory than on canopy leaves (Lowman, 1985), a pattern that did not hold for the community-wide analysis presented in here. Measurements of herbivory rates (area consumed per unit of time) are necessary to determine if herbivory really does not decrease with forest height, since differences in microclimate, leaf chemistry, and predation between the canopy and the understory are suggested to cause differences in herbivore pressure between these two forest strata (Coley \& Barone, 1996).

Also, no difference was found in standing levels of herbivory between pioneer and late successional trees. However, some other studies have shown that leaves from early successional species suffer greater damage (Coley, 1983; Dirzo, 1984; but see Newbery \& de Foresta, 1985; de la Cruz \& Dirzo, 1987). These contrasting results may be due to differences in methodology, reinforcing the need for measures of herbivory rates on central Amazonian plants before any generalizations can be made. It is also possible that pioneer trees from central Amazonian forests are better protected against herbivores than those growing in sites with better soils (e.g., Coley, 1983). In fact, leaves from many of the common pioneer species in secondary forests of Manaus (e.g., Vismia, Cecropia, Bellucia and Goupia) do show very high lignin, phenolic acid, and tannin contents (Mesquita et al., 1998).

Results from leaf palatability trials with $A$. laevigata, however, suggest that leaves from pioneer trees are more palatable to at least some herbivores. It must be noted that differences in palatability were restricted to mature leaves. No difference was observed in the palatability of young leaves from trees of different successional stages, 
and young leaves were highly preferred over mature leaves by leaf-cutting ants (Tab. 2). A greater proportion of trees in secondary forests were harbouring young leaves compared to mature forest ( 45 versus $23.3 \%$ ). This suggests that differences in leaf production between these two types of forest, perhaps more than differences in the mean palatability of mature leaves, may account for the higher abundance of leaf-cutting ants in secondary compared to primary forests.

\section{ACKNOWLEDGMENTS}

I thank Josimar F. Menezes for the collection of leaf samples from large canopy trees, and José Maria Vilhena for helping with the measurements of leaf damage. I am also grateful to Claude Gascon, Ilse Walker, and two anonymous referees for reading and commenting on previous versions of this paper. This study was supported by funding from the Conselho Nacional de Desenvolvimento Cientifico e Tecnológico (CNPq) and from the Biological Dynamics of Forest Fragments Project (INPA/ Smithsonian Institution). This represents publication number 248 in the BDFFP Technical Series.

\section{Literature cited}

Adis, J.; Furch, K.; Irmler, U. 1979. Litter production of a central-Amazonian black water inundation forest. Trop. Ecol., 20: 236- 245 .

Coley, P.D. 1983. Herbivory and defense characteristics of tree species in lowland tropical forest. Ecol. Monogr, 53: 209-233.
Coley, P.D.; Barone, J.A. 1996. Herbivory and plant defenses in tropical forests. Ann. Rev. Ecol. Sysı., 27: 305-335.

Coley, P.D.; Bryant, J.P.; Chapin, F. S., III. 1985. Resource availability and plant antiherbivore defense. Science, 230: 895-899.

de la Cruz, M.; Dirzo, R. 1987. A survey of the standing levels of herbivory in seedlings from a Mexican rain forest. Biotropica, 19: 98-106.

Dirzo, R. 1984. Insect-plant interactions: some ecophysiological consequences of herbivory. In: Medina, E.; Mooney, H.A.; Vazquez-Yanes, C. (Eds). Physiological ecology of plants of the wet tropics. Dr. Junk Publishers, The Hague. p. 209-224.

Fittkau, E.J.; Klinge, H. 1973. On biomass and trophic structure of the central Amazonian rain forest. Biotropica, 5: 2-14.

Filip, V.; Dirzo, R.; Maass, J.M.; Sarukan, J.. 1995. Within- and among-year variation in the levels of herbivory on the foliage of trees from a Mexican tropical deciduous forest. Biotropica, 27: 78-86

Guillaumet, J.L. 1987. Some structural and floristic aspects of the forest. Experientia 43: 241-251.

Jaffe, K.; Vilela, E. 1989. On nest densities of the leaf-cutting ant Atta cephalotes in tropical primary forest. Biotropica, 21: 234-236.

Jordan, C.; Uhl., C. 1978. Biomass of a "tierra firme" forest of the Amazon basin. Oecol. Plant. 13: 387-400.

Hubbell, S.P.; Wiemer, D.F. 1983. Host plant selection by an attine ant. In: Jaisson, P. (Ed). Social insects in the tropics. University of Paris, Paris. p. 133-154.

Leigh, E.G., Jr.; Smythe, N. 1978. Leaf production, leaf consumption and the regulation of folivory on Barro Colorado Island. In: Montgomery, G.G. (Ed). The ecology of arboreal folivores. Smithsonian Institution Press, Washington, D.C. p. 33-50.

Lowman, M.D. 1984. An assessment of techniques for measuring herbivory: is rainforest defoliation more intense than 
we thought? Biotropica, 16: 264-268

Lowman, M.D. 1985. Temporal and spatial variability in insect grazing of the canopies of five Australian rainforest tree species, Aust. J. Ecol., 10: 7-24.

Lucas, R.M.; Honzák, M.; Amaral, I; Curran, P.J.; Foody, G.M.; Amaral, S. 1998. Avaliação da composiçào florística, biomassa e estrutura de florestas tropicais em regeneração: a contribuição do sensoriamento remoto. $\mathrm{In}$ : Gascon, C.; Moutinho, P. (Eds). Floresta Amazônica: dinâmica, regeneração e manejo. INPA/ MCT. Manaus. p. 61-82.

Marquis, R.J.; Braker, H.E. 1994. Plant-herbivore interactions: diversity, specificity, and impact. In: McDade, L.A.; Bawa, K.S.; Hespenheide, H.A; Hartshorn, G.S. (Eds). La Selva: ecology and natural history of a Neotropical rainforest. The Chicago University Press, Chicago. p. 261-281.

Mesquita, R.C.G.; Workman, S.W.; Neely, C.L. 1998. Slow litter decomposition in a Cecropia-dominated secondary forest of central Amazonia. Soil Biol. Biochem. 30: 167-175.

Nascimento, M.T; Proctor, J. 1994. Insect defoliation of a monodominant Amazonian rainforest. J. Trop. Ecol, 10:633-636.

Newbery, D.M; de Foresta, H.. 1985. Herbivory and defense in pioneer, gap and understory trees of tropical rain forest in French Guiana. Biotropica, 17: 238-244.

Nichols-Orians, C. 1991. Environmentally induced differences in plant traits: consequences for susceptibility to a leaf-cutter ant. Ecology, 72: 1609-1623.
Ribeiro, M.N.G. 1976. Aspectos climatológicos de Manaus. Acta Amazonica, 6: 229-233.

Sterck, F,; van der Meer, P; Bongers, F, 1992. Herbivory in two rain forest canopies in French Guyana. Biotropica, 24: 97-99.

Uhl, C. 1987. Factors controlling succession following slash-and-burn agriculture in Amazonia. J. Ecol. 75: 377-407.

Vasconcelos, H. L. 1988. Distribution of Atta (Hymenoptera: Formicidae) in "terra-firme" rain forest of central Amazonia: density, species composition and preliminary results on effects of forest fragmentation. Acta Amazonica 18: 309-315.

Vasconcelos, H.L.; Cherrett, J.M. 1995. Changes in leaf-cutting ant populations after the clearing of mature forest in Brazilian Amazonia. Studies Neotrop. Fauna Environ., 30: 107-113.

Villela, D.M. 1998. Ciclagem de nutrientes em floresta de terra firme na ilha de Maracá. In: Barbosa, R.I.; Ferreira, E.F.G.; Castellón, E.G. (Eds). Homem, ambiente e ecologia no estado de Roraima. INPA, Manaus, p. 381-400.

Vitousek, P.M.; Sanford, R. L., Jr. 1986. Nutrient cycling in moist tropical forest. Ann. Rev. Ecol. Syst. 17:137-167.

Wint, G.R.W. 1983. Leaf damage in tropical rain forest canopies. In: Sutton, S. L.; Whitmore, T.C.; Chadwick, A.C. (Eds). Tropical rain forest: ecology and management. Blackwell Scientific Publications, Oxford. p. 229-239. 